\title{
Recent Advances on Catalytic Synthesis and Application of 1,1-Diborylalkenes
}

\author{
XU Nuo ${ }^{1,2}, \mathrm{HU}_{\mathrm{Yue}^{1 *}}, \mathrm{LIU}$ Chao ${ }^{1 *}$ \\ (1. Lanzhou Institute of Chemical Physics, Chinese Academy of Sciences, Lanzhou 730000, China; \\ 2. University of Chinese Academy of Sciences, Beijing 100049, China)
}

\begin{abstract}
Diborylalkenes are recognized as important synthons to access multi-substituted olefins due to their two reactive sites of boryl groups. The synthesis of different structural multi-substituted olefins can be achieved to construct new carbon-carbon bond by using Suzuki-Miyaura coupling reaction. This review intends to offer a detailed introduction of recent progress on the synthesis and application of 1,1-diborylalkene. Moreover, the prospects and promising future of 1,1-diborylalkene are also discussed.
\end{abstract}

Key word: 1,1-diborylalkene; multi-substituted olefins; catalysis; synthesis

\section{欢迎订阅《分子催化》}

《分子催化》是由中国科学院主管、科学出版社出版, 由中国科学院兰州化学物理研究所主办的向国内 外公开发行的学术刊物. 主要报导有关分子催化方面的最新进展与研究成果. 辟有学术论文、研究简报、研 究快报及进展评述等栏目. 内容侧重于络合催化、酶催化、光助催化、催化过程中的立体化学问题、催化反 应机理与动力学、催化剂表面态的研究及量子化学在催化学科中的应用等. 工业催化过程中均相催化剂、 固载化的均相催化剂、固载化的酶催化剂等的活化、失活和再生, 以及用于新催化过程的催化剂的优选与 表征等方面的稿件, 本刊也很欢迎. 读者对象主要是科研单位及工矿企业中从事催化工作的科技人员、研 究生、高等院校化学系和化工系师生. 欢迎相关专业人员投稿.

本刊为双月刊, 每逢双月末出版, 大 16 开本, 约 16 万字, 每册定价 30.00 元.

本刊为国内外公开发行. 中国标准刊号: ISSN 1001-3555/CN 62-1039/O6. 邮发代号: 54-69. E-mail 信 箱:FZCH@licp.cas.cn网址: www.jmechina.org 通过兰州市邮局发行. 亦可向本刊编辑部直接函购.

本部地址: 甘肃兰州市中国科学院兰州化学物理研究所《分子催化》编辑部

邮政编码: 730000; 电话: (0931) 4968226; 传真: (0931)8277088. 